\title{
Author Correction: Benchmarking of cell type deconvolution pipelines for transcriptomics data
}

\author{
Francisco Avila Cobos (D), José Alquicira-Hernandez (D), Joseph E. Powell, Pieter Mestdagh (1) \& \\ Katleen De Preter (10
}

Correction to: Nature Communications https:/doi.org/10.1038/s41467-020-19015-1, published online 6 November 2020.

The original version of this Article contained an error in the Acknowledgements:

'This work was supported by the European Union's Horizon 2020 research and innovation programme under grant agreement 668858

The number 668858 should have read 826121.

This has now been corrected in both the PDF and HTML versions of the Article.

Published online: 02 December 2020

\footnotetext{
(c) Open Access This article is licensed under a Creative Commons Attribution 4.0 International License, which permits use, sharing, adaptation, distribution and reproduction in any medium or format, as long as you give appropriate credit to the original author(s) and the source, provide a link to the Creative Commons license, and indicate if changes were made. The images or other third party material in this article are included in the article's Creative Commons license, unless indicated otherwise in a credit line to the material. If material is not included in the article's Creative Commons license and your intended use is not permitted by statutory regulation or exceeds the permitted use, you will need to obtain permission directly from the copyright holder. To view a copy of this license, visit http://creativecommons.org/licenses/by/4.0/.
}

(C) The Author(s) 2020 